\title{
Die "Gemeenskaplike Verklaring oor die Regverdigingsleer" van 30/31 Oktober 1999
}

\author{
I W C van Wyk ${ }^{1}$ \\ Hervormde Teologiese Kollege \\ Universiteit van Pretoria
}

\begin{abstract}
The "Joint Declaration on Justification" of 30/31 October 1999

The article deals with the historic agreement of $30 / 31$ October 1999 by the Lutherans and the Roman Catholics on the doctrine of justification. Historic information, excerpts from the text and commentary on the agreement are provided. The article also deals with the importance and relevance of this doctrine for our time.
\end{abstract}

\section{DIE HISTORIESE OOREENKOMS VAN 30/31 OKTOBER 1999}

Op 30/31 Oktober 1999 (Hervormingsdag) ${ }^{2}$ het afgevaardigdes van die Lutherse Wêreldbond (LWB) en die Rooms-Katolieke Kerk op 'n feestelike wyse in Augsburg aan die wêreld te kenne gegee dat hulle tot 'n "gemeenskaplike verklaring oor die regverdigingsleer" kon kom. Die ondertekening van hierdie gemeenskaplike verklaring was onteenseglik 'n gebeurtenis van buitengewone kerkhistoriese belang. Daar was dus tereg goeie rede om hierdie gebeurtenis in dankbaarheid teenoor God, met Duitse prag en praal te vier.

1 Prof dr I W C van Wyk is hoof van die Hervormde Teologiese Opleiding te Hammanskraal en 'n geakkrediteerde personeellid van die Hervormde Teologiese Kollege, Universiteit van Pretoria.

2 Die ondertekening van die dokument het gepaard gegaan met 'n reeks van (amptelike) perskonferensies, feesgeleenthede en eredienste wat oor die twee dae gestrek het. Om hierdie rede word daar nie net na 30 Oktober (die dag van ondertekening) verwys nie. 
Die "Gemeenskaplike Verklaring" is onderteken en uitgereik deur die Lutherse Wêreldbond en die Pouslike Raad vir die Bevordering van Eenheid onder Christene ${ }^{3}$. Die Verklaring getuig daarvan dat daar 'n "konsensus in grondwaarhede ten opsigte van die regverdigingsleer" tussen die twee kerkgemeenskappe tot stand gekom het. Die implikasie hiervan, is dat die wedersydse leerveroordelings van die $16^{\circ}$ eeu die huidige leer van die kerke in sake die regverdigingsleer, nie meer tref nie. Die leerveroordelings van die $16^{\circ}$ eeu, het dus hulle kerkskeidende werking verloor. Hierdie konsensus kan nou die basis vorm vir verdere leergesprekke, met die doelwit om Nagmaalseenheid en ander gestaltes van kerkeenheid te bevorder.

Hierdie "Gemeenskaplike Verklaring oor die Regverdigingsleer" is met groot dankbaarheid begroet. Sedert 1541/42 in Hagenau, Worms en Regensburg het hierdie twee kerke nog nie weer amptelik met mekaar gesprekke gevoer nie. Nou, 452 jaar ná die Konsilie van Trente (1547) wat die Reformasie verketter het, is daar konsensus bereik oor 'n leeraangeleentheid wat in die sentrum gestaan het van die kerkskeuring. Die volgende uitsprake van invloedryke persoonlikhede kan 'n aanduiding gee van die belangrikheid van die konsensus wat bereik is: President Friedrich Otto Scharbau van VELKD" het gesê: "Die gemeenskaplike verklaring ... makk dit duidelik, dat ons in die posisie is, om met die verskillende tradisies ... só om te gaan, dat in hierdie vrae geen kerkskeidende verskille verder gesien moet word nie ... Ons het as Lutherse Kerke en as Evangeliese Kerk in Duitsland as geheel, alreeds in die middel-sewentigerjare, 'n uitnodiging aan Rooms-Katolieke Christene gerig tot deelname aan Nagmaal in ons kerke. Ons hoop is, dat daar spoedig van 'n soortgelyke uitnodiging van die kant van die Rooms-Katolieke Kerk, gepraat sal kan word." Die voormalige landsbiskop van Beiere Hermann von Loewenich het op sy beurt gesê:

3 Ten spyte van al die opgewondenheid oor die ondertekening van hierdie teks, is dit tog jammer dat slegs die Pouslike Raad namens die Rooms-Katolieke Kerk geteken het. Die Roomse Kongregasie vir Geloofsleer, waarvan kardinaal Joseph Ratzinger die voorsitter is, het die teks nie onderteken nie. In 'n amptelike nota (vgl Jüngel 1998a:273) het die Kongregasie aangedui dat hy wel oor 'n "konsensus in grondwaarhede" sou kon praat, maar beslis nie oor 'n "konsensus in die grondwaarhede" nie. Dit beteken uiteindelik tog, dat daar nie werklik sprake kan wees van 'n konsensus met die Rooms-Katolieke Kerk nie, maar slegs met 'n raad van dié kerk. 
Ons kerke is (duidelik) gereed om die dialoogresultate amptelik aan te neem. Ons het daarvoor die model van die "gedifferensieerde konsensus" ontwikkel. Teologiese verskille hoef nou nie meer ons kerke tot in die wortels te skei nie. Die "konsensus in grondwaarhede" maak versoening moontlik. Met betrekking tot die regverdigingsleer is "versoenende verskeidenheid" tussen ons kerke nou bereik ... Die volgende stap wat nou nagejaag moet word; is gasbereidheid tot Nagmaal, wedersydse erkenning van die kerke, en uiteindelik kerklike gemeenskap.

Heinz Joachim Held (1998:163), vir jare leidende biskop in die EKD, het selfs gesê dat ons hier duidelik met 'n produk te make het wat ontstaan het onder die leiding van die Heilige Gees. Van Rooms-Katolieke kant het biskop Karl Lehmann, die voorsitter van die Duitse Biskopskonferensie gesê dat daar nou met vrymoedigheid van die "eenheid te midde van die verskeidenheid" gepraat kan word. Die biskop van Augsburg, Viktor Dammertz, se woorde was: "Só 'n tree is daar sedert die Reformasie nog nie gegée nie; dit is 'n mylpaal op die weg tot groeiende 'eenheid in versoenende verskeidenheid!' ... Die 'Gemeenskaplike Verklaring' is geen eindpunt nie, maar 'n waardevolle mylpaal, wat ons gaan help om op die weg van groeiende eenheid te bly." Walter Kasper, die sekretaris van die Pouslike Raad vir die Bevordering van die Eenheid van Christene, het op sy beurt daarop gewys dat Christus nog die aand voor sy dood, gebid het dat sy volgelinge één moet wees. Die feit dat ons nie één is nie, is nie in lyn met die wil van Christus nie. Dit is sonde en 'n skandaal voor die wêreld. Hierdie sonde word gevoed deur afgodsdiens. Ook leerstellings van die kerk kan afgode word, as hulle nie die Bybelse opdragte bevorder nie. Kasper sien in hierdie verklaring 'n corwinning oor die afgodsdiens en 'n tree in die rigting van gesamentlike Nagmaalsviering (vir volledigheid, kyk EKD 1999).

Hierdie "Gemeenskaplike Verklaring" is nie net deur die twee betrokke kerkgemeenskappe positief begroet nie, maar ook deur ander kerkgemeenskappe soos die Metodiste Kerk. Geoffrey Wainwright (1999), voorsitter van die Gesamentlike Komitee vir Gesprek tussen die Metodiste en Rooms-Katolieke, het hom ook baie positief oor hierdie Verklaring uitgelaat. Volgens hom kan die Metodiste met die meeste uitsprake saamstem. Die enigste tekortkoming is (soos te wagte) volgens hom, die ontbreking van 
uitsprake oor die werking van die Heilige Gees in die toe-eiening van die regverdigingsboodskap.

\section{DIE HISTORIESE AGTERGROND}

Die Gemeenskaplike Verklaring oor die Regverdigingsleer het nie ewe skielik uit die hemel geval nie. Dit is voorafgegaan deur dekades lange debatte en gespreksvoering tussen die twee kerkgemeenskappe. Amptelike dialoog oor leersake het beskeie begin as gesprekke van 'n "Gesamentlike Werkgroep" van Lutherse en Rooms-Katolieke toolo\& in 1965 en 1966 by die Instituut vir Ekumeniese Navorsing in Straßburg. Hierdie gesprekke het daartoe gelei dat 'n amptelike Evangelies-Lutherse/Rooms-Katolieke studiekommissie in die lewe geroep is. Hierdie Kommissie het sy werksaamhede in Oktober 1967 begin met 'n dialoog oor "die evangelie en die kerk", en dit in Februarie 1971 afgesluit met die sogenaamde "Malta-berig". Hierdie eerste fase van amptelike dialoog tussen die twee kerke was nie juis suksesvol nie, aangesien daar oor té veel sake té algemeen gepraat is.

Die tweede fase van dialoog het vanaf 1973 tot 1984 gestrek. Twee temas het in hierdie fase besondere aandag geniet, naamlik die Nagmaal (1978) en die amp (1981). Drie rapporte van die Studiekommissie het in hierdie dekade die lig gesien: "Die weg tot gemeenskap" (1980), "Wedersydse toelating tot die Nagmaal" (1982), en "Eenheid voor ons" (1985). Die positiewe van hierdie fase was die ontwikkeling van die wil om konsensus in leeraangeleenthede te bereik. Die konsep van "gedifferensieerde konsensus", wat in hierdie tyd ontwikkel is, sou die konsensus van 1999 uiteindelik ook moontlik maak (kyk Meyer 1985 vir 'n volledige oorsig oor hierdie fase). Die entoesiasme en konsensus-soekende gesindhede van hierdie fase, kan grootliks teruggevoer word na die historiese, eerste, besoek van die pous aan Duitsland in 1980. In Mainz, het die toenmalige voorsitter van die EKD, Eduard Lohse, aan die pous 'n reeks konkrete voorstelle gemaak, oor hoe die verhoudinge tussen die twee kerke verbeter sou kon word. Hy het aanbeveel dat daar gesamentlike eredienste gehou moet word, dat daar gesamentlike pastorale diens gelewer moet word aan mense in gemengde huwelike, en dat daar 'n oop uitnodiging na die Nagmaal sal wees. Laasgenoemde was natuurlik nie in die Rooms-Katolieke Kerk moontlik nie, aangesien hulle die Evangeliese Kerk nog nie as 
kerk erken het nie. Die rede daarvoor: die onenigheid in kerklike leer. Daar is toe op 'n gesamentlike biskopskommissie besluit wat moes poog om struikelblokke in die weg van groter kerklike eenheid uit die weg te ruim. Op 6 Mei 1981 het Lohse en kardinaal Josef Ratzinger voorgestel dat daar aan die kerke bewys moet word dat daar oor die sentrale leerstuk van die regverdiging eenstemmigheid bestaan en dat die leerveroordelings van die $16^{\mathrm{C}}$ eeu die kerke in hulle huidige leer oor hierdie saak nie meer tref nie. Hierdie taak is toe na bogenoemde Gesamentlike Kommissie verwys vir afhandeling. Omdat die vermoede sterk geleef het dat daar nie meer groot en onoorbrugbare verskille tussen die kerke bestaan oor hierdie leerstuk nie, is daar met ywer en entoesiasme gewerk.

Die amptelike dialoog het in 1986 'n derde fase binnegegaan. Hierdie fase is gekenmerk deur die ongelooflike intensiteit en uitgebreidheid van debatvoering asook van verslag- en beriggewing. Al die inligting is te vinde in die publikasiereeks "Leerveroordelings - kerkskeidend?" uitgegee deur Wolfhart Pannenberg en Karl Lehmann, waarvan band 1 in 1986 verskyn het. In hierdie eerste band is daar uitvoerig berig oor die resultate van onder andere die gesprek oor die regverdigingsleer. Uit hierdie publikasie en die kommentaar wat daarop gelewer is, blyk dit dat daar alreeds teen 1986 onder die ekumeniese gesprekvoerders konsensus bereik is oor die regverdigingsleer. Sekere teoloě en kerkleiers kon egter nie met die dialoogresultate instemming betuig nie. Twee duidelike fronte het dus rondom 1986 binne Lutherse geledere na vore getree. Aan die een kant was daar die ekumeniese gesprekvoerders en dosente wat die dialoog en die "konsensusresultate". verdedig het. Een van die belangrike persoonlikhede aan hierdie kant van die lyn was Wolfhart Pannenberg. Pannenberg $(1991,1992)$ het moeite gedoen om die skeptici en kritici te cortuig dat die Lutherse verteenwoordigers op die gesamentlike komitee nie voor die Rooms-Katolieke gekapituleer het nie. Hy het die moeilike weg van konsensussoeke verduidelik, en hulle verseker dat geen Lutherse grondwaarhede prysgegee word nie. Hulle moes verstaan dat die buitewerkingstelling van ou leerverskille maar slegs die begin is van ekumeniese konsensusvorming. Aan die ander kant was daar persone uit die kerkleiding, dosente en selfs teologiese fakulteite (soos Gottingen) wat 'n besondere verpligting teenoor die Lutherse belydenis aanvaar, wat gevoel het dat daar teologiese verraad gepleeg is. Superintendent Emst Volk (1988) het selfs so ver gegaan om te beweer dat die Reformatoriese sekerhede ten gunste van die 
onsekerhede van Trente prysgegee is - met die gevolg (volgens hom) dat die evangelie self prysgegee is. Reinhard Slenczka (1987) was een van die teoloê wat hierdie ooreenkoms in die regverdigingsleer gekritiseer het. Volgens Kandler was die coreenkoms slegs moontlik, omdat die Lutherse afgevaardigdes ontrou was aan hulle eie teologiese tradisie. Daar was egter ook 'n middelgroep, waaronder mense soos Kandler, wat huiwerig was in hulle oordeel. Volgens Kandler (1990:21) was die resultaat van die dialoog - 'n hoe graad van eenstemmigheid oor die verstaan van die regverdiging - niks minder nie as ' $n$ wonder van die Heilige Gees. Hierdie eenstemmigheid het volgens hom die weg gebaan vir 'n toekomstige werklikheid van "versoenende verskeidenheid", waar daar nie meer ruimte sal wees vir leerveroordelings nie. Op 'n versigtige wyse het hy egter gewaarsku dat daar nog nie sprake van konsensus kan wees nie, aangesien daar nie werklik eenstemmigheid is (en seker nooit kan wees) oor die rang van die regverdiging nie. Hy het daarop gewys dat die Rooms-Katolieke nog steeds meen dat die regverdigingsleer ' $n$ leer naas andere is, terwyl dit vir die Lutherane niks minder as die grondbestemming en maatstaf van teologiese kennis is nie. Dit is die grondvraag na die menslike heil, die hart van die evangelie, aangesien dit oor skuld en vergewing gaan. Verder het Kandler (1990:214-216) daarop gewys dat die Rooms-Katolieke nog steeds met die gedagte van "regverdigmaking" as 'n proses werk, terwyl die Lutherane weer met die oortuiging werk dat regverdiging "regverdig verklaring" is wat geen proseskarakter kan vertoon nie. Volgens hom plaas die Rooms-Katolieke nou wel groter klem op die genade, maar eindig nog steeds by die werke as voltooiing van die redding. Volgens die Lutherane is die genade nie slegs die eerste stap op die weg van die heil nie, maar is self die heil. Uiteindelik kom dit maar weer daarop neer dat die Rooms-Katolieke, volgens hom, nog steeds nie die regverdiging as gans die werk van Christus beskou nie.

'n Vyfde fase (ten spyte daarvan dat dit met die vorige fase oorvleuel het) het vanaf 1986 tot en met 1994 geloop. Die debat met Rome, maar cok die binne-Lutherse twisgesprekke, het almal in hierdie tyd laat besef dat die gesprek oor die regverdigings. . leer, die kerk en haar identiteit direk raak. In 1994 het die Gesamentlike Kommissie 'n

5 Die fronte wat hier gevorm is, is in 'n groot mate dieselfde fronte wat hulle self voondoen rondom die "Gemeenskaplike Verklaring". Byna dieselfde persone, institute en fakulteite staan nog steeds teenoor mekaar en beveg mekaar met mag en mening. 
besprekingsdokument "Kerk en regverdiging" bekend gestel. Hierdie dokument het 'n hewige debat ontketen (kyk o a Wendebourg 1996). Talle artikels oor die tema "regverdiging en ekklesiologie" (soos o a Kandler 1989; Schwarzwaller 1989; Jenson 1996; Klaiber 1996; Hendrix 1997; Lohse 1997; Grane 1998; Theobald 1998) het daarom vanaf hierdie tyd die lig gesien. Daar is aan die een kant besef dat konsensus met Rome slegs moontlik is, as daar konsensus is oor die ekklesiologiese implikasies van die regverdigingsleer. Aan die ander kant is daar ook besef dat Reformatoriese sowel as RoomsKatolieke identiteit bedreig word deur onnoukeurige en onnadenkende uitsprake oor die ekklesiologiese konsekwensies van die regverdigingsleer. Om identiteit te midde van ekumenisiteit te beskerm, moes daar dus duidelikheid kom oor die verhouding "kerk regverdiging".

Die sesde fase was die fase waarin verskillende konsepte van die "Gemeenskaplike Verklaring" die lig gesien het. Op 30 Januarie 1995 het die sekretaris-generaal van die Lutherse Wêreldbond, dr Ishmael Noko, die eerste konsep ${ }^{6}$ aan die 122 lidkerke gestuur, met die versoek dat die kerke moet sê of die konsensus wat bereik is, met die Skrif en die Lutherse belydenisskrifte versoenbaar is? ${ }^{7}$ Daar was van Duits-Lutherse kant nie baie positiewe reaksie op hierdie eerste konsep nie. Daar was onduidelikheid en ongelukkigheid oor die ontstaansproses van die teks (kyk Wendebourg 1998:147-156 vir 'n oorsig van al die probleme). Dit het daartoe gelei dat 'n tweede konsep in 1996 die lig gesien het. Vir die finalisering van hierdie konsep is daar van baie meer kundigheid wêreldwyd gebruik gemaak as voorheen (maar, opmerklik nie van grootnaam Duitse kundigheid nie). Vir weke lank is daar aan die verandering en verbetering van die teks gewerk (kyk Wendebourg 1998:156-167). Ook hierdie konsep is deur die lidkerke bespreek en gekritiseer. Weereens is daar aan die teks gewerk, veral onder druk van die Duitse Kerk wat heftige kritiek gelewer het. Uiteindelik is die finale produk op 27 Januarie 1997 aan die lidkerke gestuur. In die meeste lande is hierdie teks deur beide die Lutherse en Rooms-Katolieke Kerk kritiekloos aanvaar. Duitsland was egter weer 'n

6 Hierdie eerste konsep, soos trouens ook die tweede konsep, kan saam met die amptelike korrespondensie van die sekretaris-generaal, gevind word in Wendebourg (1998:168-206).

7 Hier is nie gevra of die konsensus wat voorgele is, inderdaad 'n konsensus is nie? - Wendebourg (1998:141). 
uitsondering. Heftige debatte het in gemeentes, fakulteite en sinodes gewoed. Aan die een kant was daar mense wat gevra het dat VELKD hierdie teks moet aanvaar en dat daar ekumenies saamgewerk moet word. Aan die ander kant was daar teoloe (veral dogmatici) wat gemeen het dat die Lutherse Kerk haar teologiese integriteit sal prysgee met die aanvaarding van die inhoud van hierdie teks. Soos almal nou weet, het VELKD, met tóg 'n gevoel van onvergenoegdheid, wel die teks onderskryf.

\section{DIE “GEMEENSKAPLIKE VERKLARING” VAN 1997}

\section{Aanhef}

(1) Die leer van die regverdiging het vir die Lutherse Reformasie van die $16^{\circ}$ eeu sentrale betekenis gehad. Dit het vir haar gegeld as "eerste en hoofartikel", wat tegelyk "begeleier en regter oor alle stukke van die Christelike leer is". Op ' $n$ heel besondere wyse is die regverdigingsleer in die Reformatoriese gestalte ... verdedig teenoor die RoomsKatolieke teologie en Kerk, wat 'n ander gestalte van regverdigingsleer voorgedra en verdedig het. Hier, het uit Reformatoriese gesigspunt, die kempunt van al die twispunte gelê. Die resultaat (van die twis en meningsverskille) was leerveroordelings (soos opgeneem) in die Lutherse belydenisskrifte en (geformuleer soos) op die konsilie van Trente van die Rooms-Katolieke Kerk, wat tot vandag toe nog geldigheid en kerkskeidende werking het. (2) Die regverdigingsleer het vir die Lutherse tradisie hierdie besondere posisie behou. Daarom het dit ook in die amptelike Luthers-Katolieke dialoog van die begin af 'n belangrike plek ingeneem. (3) Op 'n besondere wyse word hier gewys op die berigte "evangelie en kerk" (1972), "kerk en regverdiging" (1994) ... "regverdiging deur die geloof" (1983) en "leerveroordelinge - kerkskeurend?" (1986) (as produkte van die ekumeniese dialoogvoering). (4) Al die genoemde dialoogberigte, en ook al die standpunte oor (hierdie dokumente), het bewys dat daar 'n ho\& mate aan gemeenskaplike visie en oordeel bestaan. Dit het daarom tyd geword om balans te trek en die resultate van die gesprekke oor die regverdiging op só 'n wyse saam te vat, dat ons kerke presies, maar

8 Wat hier volg, is uittreksels uit die teks soos dit te vinde is by Wendebourg (1998:168-198). Aangesien die "Verklaring" 'n lang, uitgebreide dokument is, kan die teks in sy geheel nie hier herhaal word nie. Daar word gehoop dat hiendie uittreksels aan $\mathbf{u}$ 'n idee sal gee van die wese, aard en inhoud van die teks. Daar is gepoog om sover moontlik letterlik te vertaal. Weens die uitsonderlike kriptiese aard van die teks, kan daar meestal nie aan hierdie ideal voldoen word nie. Ek moes vir groot gedeeltes 'n "hermeneutiese vertaalstyl" volg. 
kortliks oor die totale resultaat van hierdie dialoog ingelig kan word, en dat hulle (op grond hiervan) in staat sal wees om hulle bindend daaroor uit te spreek. (5) Dit wil die gemeenskaplike (Gemeinsame') verklaring doen. Dit wil bewys lewer dat, op grond van die dialoog, die ondertekenende Lutherse en Rooms-Katolieke Kerke, nou in staat is om 'n gemeenskaplike verstaan van ons regverdiging deur God se genade in geloof aan Christus voor te dra. Dit (hierdie verklaring) bevat nie alles wat in die onderskeie kerke oor die regverdiging geleer word nie; dit omvat egter 'n konsensus in grondwaarhede van die regverdigingsleer, en bewys dat die onderskeie uiteensettings wat mag volg, nie langer aanleiding sal gee vir leerveroordelings nie. ... (7) Soos die dialoè self, word die gemeenskaplike verklaring deur die oortuiging gedra, dat 'n agterwee laat van die kontroversvrae en leerveroordelings van die verlede, nie die (leer)skeidings en veroordelings (van die verlede) ligtelik opneem nie, en ook nie die eie kerklike verlede verwerp niè. Dit word egter deur die oortuiging gedra dat ons kerke deur die loop van die geskiedenis nuwe insigte bekom het, en dat ontwikkelinge plaasgevind het ${ }^{10}$, wat dit vir hulle nie net moontlik maak nie, maar dit ook gebiedend noodsaaklik maak, dat die skeidende vrae en veroordelings hersien en in 'n nuwe lig gestel word.

\subsection{Bybelse regverdigingsboodskap}

(8) Die manier en wyse waarop ons gesamentlik God se Woord in die Heilige Skrif gehoor het, het ons tot hierdie nuwe insigte gebring. Gemeenskaplik hoor ons die evangelie dat "God die wêreld so lief gehad het ..." (Joh 3:16). Hierdie blye boodskap word in die Heilige Skrif op verskillende wyses daargestel. In die Ou Testament hoor ons die Woord van God (wat handel oor) die menslike sondigheid ${ }^{11}$... van die menslike ongehoorsaamheid ... sowel as van die geregtigheid ... en die gerig van God ... (9) In die Nuwe Testament word by Matteus ... Johannes ... in die Hebreërbrief ... en in die Jakobusbrief ... die temas "geregtigheid" en "regverdiging" verskillend behandel. Ook in die Pauliniese briewe word die gawe van die heil op verskillende maniere beskryf, onder andere as: "bevryding tot vryheid" ... "versoening met God" ... "vrede met God" ... "nuwe

9 "Gemeinsame Erklărung" sou ook vertaal kon word as "Gesamentlike Verklaring", maar hierdie woord gee minder van die Duitse betekenis weer as gemeenskaplik.

10 Hier word bedoel: die aanvaarding van die histories-kritiese eksegese deur Vaticanum II.

11 Weens 'n ruimtegebrek kan die talle teksverwysings nie in hierdie teks opgeneem word nie. 
skepping" ... "lewe vir God in Christus" ... "heiliging in Christus Jesus" ... Uitstaande onder hierdie tiperings is die beskrywing "regverdiging" van die sondaar deur God se genade in die geloof (Rom 3:23-25), wat in die tyd van die Reformasie besondere aandag geniet het. (10) Paulus beskryf die evangelie as die krag van God tot redding van die mens wat in sonde geval het: as boodskap wat die "geregtigheid van God uit die geloof tot geloof" (Rom 1:16v) verkondig en die "regverdiging" (Rom 3:21-31) skenk. Hy verkondig Christus as "ons geregtigheid"... In die dood en opstanding van Christus is al die dimensies van sy verlossingswerk gewortel ... (11) Regverdiging is sondevergewing ... bevryding van die heersende mag van die sonde en die dood ... en van die vloek van die wet ... Dit is opname in die gemeenskap met God, nou alreeds, volkome egter eers in die toekomstige ryk ... Dit verenig met Christus en sy dood en opstanding ... Dit geskied in die ontvangs van die Heilige Gees in die doop as inlywing in sy liggaam ... Dit alleš kom alleen van God om Christus se ontwil, uit genade deur die geloof aan die "evangelie van die Seun van God" (Rom 1:1-3). (12) Die geregverdigde lewe uit die geloof, wat uit die Woord van God kom ... en in die liefde werk ... wat die vrug van die Gees is ... Maar, aangesien daar magte en begeerlikhede is wat die gelowiges uiterlik en innerlik beveg ... en hulle in die sonde laat val ... moet hulle die beloftes van God altyd weer aanhoor, hulle sondes bely ... aan die liggaam en bloed van Christus deelneem, en vermaan word om in ooreenstemming met die wil van God, in geregtigheid te lewe ....

\subsection{Die regverdigingsleer as ekumeniese probleem}

(13) Die verskil in uitleg en aanwending van die Bybelse boodskap van die regverdiging, was in die $16^{e}$ eeu een hoofrede vir die skeuring van die Europese Kerk, wat uiteindelik in leerveroordelings uitgeloop het. Vir die herstel van hierdie kerkskeuring, is 'n gemeenskaplike verstaan van die regverdiging, grondliggend en onmisbaar. Deur die aanvaarding van (nuwere) Bybelwetenskaplike-, teologiese- en dogmenhistoriese navorsingsresultate in die ekumeniese dialoog sedert die Tweede Vatikaanse Konsilie, het daar 'n duidelike eenheidsverstaan ontwikkel, sodat daar in hierdie Verklaring sprake kan wees van 'n konsensus in die grondwaarhede van die regverdigingsleer, in die lig waarvan die leerveroordelings van die $16^{\circ}$ eeu die huidige gespreksgenote nie meer tref nie. 


\subsection{Die gemeenskaplike verstaan van die regverdiging}

(14) Die gesamentlike luister na die blye boodskap wat in die Heilige Skrif verkondig word, en nie soseer die teologiese gesprekke van die laaste jare tussen die Lutherse Kerke en die Rooms-Katolieke Kerk nie, het tot 'n gemeenskaplikheid in die verstaan van die regverdiging gelei. Dit (hierdie gemeenskaplike verstaan) omvat 'n konsensus in die grondwaarhede; die verskillende gestaltegewings (hiervan) in deelaspekte (van die regverdigingsleer) is hiermee versoenbaar. (15) Dit is ons gemeenskaplike geloof dat die regverdiging die werk van die Drie-enige God is. Die Vader het sy Seun tot heil vir die sondaar na die wêreld gestuur. Die menswording, die dood en die opstanding van Christus is die grond en voorwaarde van die regverdiging. Daarom beteken regverdiging, dat Christus self ons regverdiging is, wat ons volgens die wil van die Vader deur die Heilige Gees deelagtig word. Gemeenskaplik bely ons: Alleen uit genade in geloof aan die heilsdaad van Christus, nie op grond van ons verdienste nie, word ons deur God aangeneem en ontvang ons die Heilige Gees, wat ons harte vernuwe en ons in staat stel en oproep tot goeie werke. (16) Alle mense is deur God tot heil geroep. Alleen deur Christus word ons geregverdig, deurdat ons in geloof hierdie heil ontvang. Die geloof self, is egter weer 'n geskenk van God deur die Heilige Gees, wat in Woord en sakrament in die gemeenskap van gelowiges werk, en tegelykertyd die gelowiges tot vernuwing van hulle lewens lei, wat God in die ewige lewe sal voleindig. (17) Gemeenskaplik is ons van oortuiging dat die boodskap van die regverdiging ons op 'n besondere wyse na die hart van die Nuwe-Testamentiese getuienis van God se heilshandeling in Christus heenlei: dit (hierdie getuienis) sê aan ons, dat ons as sondaars ons nuwe lewe alleen te danke het aan die herskeppende barmhartigheid van God, wat ons ons slegs kan laat skenk en in geloof kan ontvang, maar nie - in watter vorm ook al - kan verdien nie. (18) Daarom is die leer van die regverdiging, wat hierdie boodskap opneem en ontvou, nie slegs 'n deelstuk van die Christelike geloofsleer nie. Dit staan in 'n wesenlik verhouding tot alle geloofswaarhede, wat onder mekaar in ' $n$ innerlike samehang gesien moet word. Dit is 'n onmisbare kriterium, wat die totale leer en praktyk van die kerk onophoudelik aan Christus wil oriěnteer. Wanneer Lutherane die unieke betekenis van hierdie kriterium beklemtoon, ontken hulle nie die samehang en die betekenis van alle geloofswaarhede nie. Wanneer Rooms Katolieke hulle teenoor meerdere kriteria verplig sien; ontken hulle 
nie die besondere funksie van die regverdigingsboodskap nie. Lutherane en Rooms Katolieke het die gemeenskaplike doelwit, om in alles Christus te bely ...

\subsection{Die ontvouing van die gemeenskaplike verstaan van die regverdiging}

\subsubsection{Onvermoz en sonde van die mens in die lig van die regverdiging}

(19) Ons bely gemeenskaplik dat die mens ten opsigte van sy heil volledig op die reddende genade van God aangewese is. Die vryheid wat hy teenoor die mense en dinge van die wêreld besit, is geen vryheid ten opsigte van sy heil nie. Dit beteken: as sondaar staan hy onder die gerig van God en is nie in staat om hom uit homself tot God vir redding te wend nie, of om sy regverdiging voor God te verdien nie, of om met eie krag sy heil te skep nie. Regverdiging geskied alleen uit genade. Omdat Rooms Katolieke en Lutherane dit gemeenskaplik bely, geld dit dat: (20) Wanneer Rooms Katolieke sê dat die mens by die voorbereiding op die regverdiging en die aanname daarvan deur in te stem tot God se regverdigende handeling, "meewerk" (tot sy heil), sien hulle in só 'n persoonlike instemming self ' $n$ werking van die genade en geen daad van die mens uit eie kragte nie. (21) Volgens Lutherse opvatting is die mens nie daartoe in staat om tot sy redding mee te werk nie, omdat hy as sondaar aktief God en sy reddende handeling teenstaan. Lutherane ontken egter nie dat die mens die werke van die genade kan verwerp nie. Wanneer hulle beklemtoon, dat die mens die regverdiging net kan ontvang (mere passive), verwerp hulle daarmee enige moontlikheid van 'n bydrae van die mens tot sy regverdiging, maar nie sy volle persoonlike deelname in geloof, wat deur die Woord van God self gewerk word nie.

\subsubsection{Regverdiging as sondevergewing en regverdigmaking}

Ons bely gemeenskaplik dat God uit genade die mens die sonde vergewe en hom tegelyk tydens sy lewe van die knegtende mag van die sonde bevry en aan hom die nuwe lewe in Christus skenk. Wanneer die mens aan Christus in die geloof deel het, reken God hom sy sonde nie toe nie en bewerk in hom dade van liefde deur die Heilige Gees. Beide aspekte van God se genadehandeling mag nie van mekaar geskei word nie ... Omdat Rooms Katolieke en Lutherane dít gemeenskaplik bely, daarom geld dit dat: (23) 
Wanneer Lutherane dit beklemtoon dat Christus se geregtigheid ons geregtigheid is, wil hulle veral daaraan vashou, dat deur die toesegging van die vergewing van sondes, aan die mens geregtigheid voor God in Christus geskenk word en sy lewe slegs in verbinding met Christus vernuwe word. Wanneer hulle sê dat God se genade vergewende liefde (guns van God) is, ontken hulle daarmee nie die vernuwing van die lewe van die Christen nie, maar wil tot uitdrukking bring dat die regverdiging vry bly van menslike medewerking en ook nie van die lewensvernuwende werking van die genade in die mens afhanklik is nie. (24) Wanneer die Rooms Katolieke beklemtoon dat die gelowige die vernuwing van die innerlike mens deur die ontvangs van die genade geskenk word, dan wil hulle daaraan vashou dat die vergewende genade van God altyd met die geskenk van 'n nuwe lewe verbonde is, wat sig deur die Heilige Gees in dade van liefde laat uitmond. Hulle ontken daarmee nie dat God se genadegawe in die regverdiging onafhanklik van menslike meewerking bly nie.

\subsubsection{Regverdiging deur geloof en uit genade}

(25) Ons bely gemeenskaplik dat die sondaar deur die geloof aan die heilshandeling van God in Christus geregverdig word; hierdie heil word aan hom deur die Heilige Gees in die doop, as fondament van sy ganse Christelike lewe, geskenk. Die mens vertrou in die regverdigende geloof op God se genadige belofte, wat die hoop op God en die liefde jeens Hom, insluit. Hierdie geloof is doenig in die liefde. Daarom kan en mag die Christen nie sonder werke wees nie. Maar, alles wat in die mens die vrye geskenk van die geloof voorafgaan en daaruit voortspruit, is nie grond van die regverdiging nie en verdien niks nie. (26) Volgens Lutherse verstaan, regverdig God die sondaar alleen in die geloof (sola fide). In die geloof vertrou die mens geheel en al op sy Skepper en Verlosser, en is só in gemeenskap met Hom. God self bewerk die geloof, deurdat Hy deur sy skeppende Woord die vertroue na vore bring. Omdat hierdie daad van God 'n nuwe skepping is, raak dit alle dimensies van die persoon en lei dit tot 'n lewe in hoop en liefde. So word die leer van die "regverdiging deur die geloof alleen" die vernuwing van die lewensvoering, wat noodwendig uit die regverdiging volg en waarsonder die geloof nie kan wees nie, wat weliswaar van die regverdiging onderskei maar nie daarvan geskei kan word nie ... vanuit die liefde van God, wat die mens in die regverdiging geskenk 
word, groei die vernuwing van die lewe. Regverdiging en vernuwing is deur die geloof aan die teenswoordige Christus verbonde. (27) Ook volgens Rooms-Katolieke verstaan, is die geloof vir die regverdiging fundamenteel; want sonder die geloof kan daar geen regverdiging wees nie. Die mens word as hoorder van die Woord en as gelowige daarin, deur die doop geregverdig. Die regverdiging van die sondaar is sondevergewing en regverdigmaking deur die regverdigingsgenade, wat ons tot kinders van God maak. In die regverdiging ontvang die geregverdigde van Christus geloof, hoop en liefde en word só in die gemeenskap met Hom opgeneem. Hierdie nuwe persoonlike verhouding met God, grond geheel en al in die genadigheid van God ... Daarom word die regverdigingsgenade nie besit van die mens nie ... Wanneer, volgens Rooms-Katolieke verstaan, die vernuwing van die lewe deur die regverdigingsgenade beklemtoon word, is hierdie vernuwing in geloof, hoop en liefde altyd op die grondlose genade van God aangewese en lewer geen bydrae tot die regverdiging nie ....

\subsubsection{Die sondaar-wees van die geregverdigte}

(28) Ons bely gemeenskaplik dat die Heilige Gees in die doop die mens met Christus verenig, regverdig en hom werklik vernuwe. En tog bly die geregverdigde sy hele lewe lank ... op die genade van God aangewese ... Ook die geregverdigde moet soos in die Onse Vader God daagliks om vergewing bid ... (29) Die Lutherane verstaan dit in hierdie sin, dat die Christen "tegelyk geregverdigde en sondaar" is ... (30) Die Rooms Katolieke is van mening dat die genade van Jesus Christus, wat in die doop verleen word, alles wat "werklik" sonde was ... uitdelg, maar dat daar nogtans 'n neiging (konkupisens), wat uit die sonde kom en tot sonde stuur, in die mens bly ...

\subsubsection{Wet en evangelie}

(31) Ons bely gemeenskaplik dat die mens in geloof aan die evangelie "onafhanklik van die werke van die wet" (Rom 3:28) geregverdig word. Christus het die wet vervul en dit deur sy dood en opstanding as weg tot die heil oorwin. Ons bely tegelyk dat die gebooie van God vir die geregverdigde geldigheid behou, en dat Christus in sy Woord en lewe die wil van God, wat ook vir die geregverdigde rigsnoer van sy handeling is, tot uitdrukking gebring het. (32) Die Lutherane wys daarop dat die onderskeiding en regte ordening van 
wet en evangelie wesenlik is vir die verstaan van die regverdiging ... (33) Omdat die wet as heilsweg deur die evangelie vervul en oorwin is, kan die Rooms Katolieke sê dat Christus nie 'n wetgewer in die sin van Moses is nie. Wanneer Rooms Katolieke dit beklemtoon dat die geregverdigde tot gehoorsaamheid aan die gebooie van God verplig is, ontken hulle nie daarmee dat die genade van die ewige lewe aan die kinders van God deur Jesus Christus erbarmingsvol belowe is nie.

\subsubsection{Heilsekerheid}

(34) Ons bely gemeenskaplik dat die gelowiges hulle op die barmhartigheid en die beloftes van God kan verlaat. Ook, in die lig van hulle eie swakheid en menigvuldige bedreigings van hulle geloof, kan hulle danksy die dood en opstanding van Christus, op die werkende toesegging van die genade van God in Woord en sakrament bou, en op hierdie wyse van die genade seker wees. (35) Dit is op 'n besondere wyse deur die Reformatore beklemtoon: in die aanvegting moet die gelowige nie na homself, maar na Christus kyk en Hom alleen vertrou. So is hy in vertroue op God se toesegging, van sy heil seker ... (36) Rooms Katolieke kan hierdie invalshoek van die Reformatore deel, om geloof op die objektiewe werklikheid van die belofte van Christus te begrond, van die eie ervaring af te sien en op Christus se woord van belofte alleen te vertrou :.. Met die Tweede Vatikaanse Konsilie sê Rooms Katolieke: geloof beteken, om jouself geheel en al aan God toe te vertrou, wat ons uit duisternis van sonde en dood bevry en tot ewige lewe verwek. ' $n$ Mens kan in hierdie sin nie aan God glo nie, en tegelyk sy Woord van belofte nie vertrouenswaardig ag nie. Niemand mag aan God se barmhartigheid en aan Christus se verdienste twyfel nie ... In sy totale bewussyn om sy eie mislukking, mag die gelowige daarvan seker wees, dat God sy heil wil.

\subsubsection{Die goeie werke van die geregverdigde}

(37) Ons bely gemeenskaplik dat goeie werke - 'n Christelike lewe in geloof, hoop en liefde - op die regverdiging volg en vrugte van die regverdiging is ... Hierdie gevolg van die regverdiging is vir die Christen, in soverre hy daagliks teen die sonde stry, 'n verpligting wat hy moet vervul; om hierdie rede vermaan Jesus en die apostoliese geskrifte die Christene, om werke van die liefde te doen. (38) Volgens Rooms-Katolieke opvatting, dra die goeie werke ... tot 'n toename in genade by, sodat die geregtigheid wat 
van God ontvang is, bewaar word en die gemeenskap met Christus verdiep word. Wanneer Rooms Katolieke aan die "verdienstelikheid" van die goeie werke vashou, wil hulle daarmee sê dat volgens Bybelse getuienis, 'n hemelse loon daarvoor belowe is. Hulle wil die verantwoordelikheid van die mens vir sy handeling beklemtoon, maar daarmee nie die geskenkkarakter van die goeie werke bestry nie, en beslis nie ontken dat die regverdiging self altyd 'n onverdiende genadegeskenk bly nie. (39) Ook by Lutherane bestaan daar die gedagte van ' $n$ bewaring van die genade en 'n groei in genade en geloof. Hulle beklemtoon egter, dat die geregtigheid as aanname deur God en as deelname aan die geregtigheid van Christus, altyd volkome is, maar sê egter tegelyk dat die uitwerking daarvan in die Christelike lewe kan groei. Wanneer hulle die goeie werke van die Christen as "vrugte" en "teken" van die regverdiging, en nie as eie "verdienste" beskou nie, verstaan hulle tog die ewige lewe, op grond van die Nuwe Testament, as onverdiende "loon", en wel in die sin van die vervulling van God se toesegging aan die gelowiges.

\subsection{Die betekenis en draagwydte van die bereikte konsensus}

(40) Die verstaan van die regverdigingsleer soos in hierdie verklaring daargestel, wys dat daar tussen Lutherane en Rooms Katolieke 'n konsensus in grondwaarhede van die regverdigingsleer bestaan. In die lig hiervan is die blywende verskille in taal, teologiese gestaltegewing en aksente van die regverdigingsverstaan, soos in nommers 18-36 beskryf, draaglik. Daarom is die verskillende Lutherse en Rooms-Katolieke ontvouings van die regverdigingsgeloof oop vir mekaar, en hef dit die konsensus in grondwaarhede nie weer op nie. (41) Daarmee verskyn die leerveroordelings van die $16^{\mathrm{e}}$ eeu ... in 'n nuwe lig: die Lutherse verklaring oor die regverdigingsleer wat in hierdie verklaring voorgelê is, word nie deur die veroordelings van die Konsilie van Trente geraak nie. Die verwerpings van die Rooms-Katolieke leerstellings deur die Lutherse belydenisskrifte raak nie die leer van die Rooms-Katolieke Kerk soos in hierdie verklaring voorgelê nie. (42) Daarmee word die leerveroordelings wat op die regverdigingsleer betrekking gehad het, nie van hulle erns ontneem nie. Etlike van hulle was nie bloot substansieloos nie ... (43) Ons konsensus in grondwaarhede van die regverdigingsleer moet werking hê in die lewe en leer van die kerke, en dáár tot sy volle reg kom. Daar bestaan nog egter vrae van 
verskillende gewig, wat verdere uitklaring nodig het: dit raak onder andere die verhouding van die Woord van God en kerklike leer, sowel as die leer oor die kerk ... en die verhouding tussen regver-diging en sosiale etiek. Ons is egter daarvan oortuig dat die bereikte gemeenskaplike verstaan, 'n stewige grondslag bied vir só 'n uitklaring. Die Lutherse Kerke en die Rooms-Katolieke Kerk gaan hulle verder daarvoor beywer, om hierdie gemeenskaplike verstaan te verdiep en om dit in die kerklike leer en kerklike lewe vrugbaar te maak. (44) Ons dank die Here vir hierdie belangrike stap tot oorwinning oor die kerkskeuring. Ons bid die Heilige Gees, om ons tot daardie sigbare eenheid verder te lei, wat die wil van Christus is.

\section{REAKSIES EN KOMMENTAAR OP DIE “GEMEENSKAP- LIKE VERKLARING"}

Hierdie verklaring het, soos ons nou reeds weet, ongekende reaksie in Duitsland ${ }^{12}$ ontketen (kyk na Wallmann 1998 vir volledige insae in hierdie uitbarsting). Die reaksie, wat selfs deur die openbare dagpers gedra is, was aan die een kant, entoesiasties en positief. Daar is gepraat van 'n "ekumeniese deurbraak", 'n "beslissende stap op pad na kerkeenheid" en selfs van "eenheid buite 'n eenheidskerk" (vgl Sauter 1999a:33). H G Pöhlmann (epd 16.9.97) het selfs gepraat van 'n "ekumeniese wêreldsensasie". Aan die ander kant was daar ontsteltenis en teleurstelling. Soos in die geval van die vorige gespreksfases, was dit teoloe onder die leiding van toonaangewende dogmatici, wat ontsteltenis uitgespreek het. Ingolf Dalferth (Zürich) (1997) en Eberhard Jüngel (Tübingen) (1997) het die protes gelei. Die alarm wat hulle gemaak het, het daartoe aanleiding gegee dat 'n groep van 153 dosente onder leiding van Gerhard Ebeling hulle op 6 Januarie 1998 van hierdie verklaring gedistansieer het. Volgens hulle, is daar en kan daar nie sprake wees van 'n konsensus met die Rooms Katolieke oor die regverdigingsleer nie. Volgens hulle moet daar niks, wat van die Protestantse waarde is, teenoor die Rooms Katolieke prysgegee word nie (kyk na Wallmann 1998:228-233 vir die ontstaan en reaksies op die protesnota van die dosente). Die indruk is met hierdie groep se persverklaring gewek dat alle "grootnaam-teoloe”" hulle van hierdie verklaring gedistan-

12 Naas Duitsland, was daar slegs in Finland en Denemarke openbare debat oor hierdie verklaring. 
sieer het. Dít is egter nie waar nie. Op 2 April 1998 het 'n groep met ewe eens groot name, soos Eduard Lohse, Wolfhart Pannenberg, Ulrich Wilckens en Alasdair Heron, hulle weer ten gunste van hierdie verklaring uitgespreek ${ }^{13}$. Hans-Martin Barth, die president van die Evangeliese Bond, het byvoorbeeld gesê dat daar nie met 'n alles of niks houding gewerk kan word nie. Verder het hy daarop gewys dat hierdie debat oor die regverdigingsleer die Rooms Katolieke gedwing het om oor hulle hele teologie weer ernstig te herbesin. Dit is daarom nie die Lutherane wat met die grootste ongemak uit die stryd getree het nie, maar die Rooms-Katolieke. Wat uiteindelik blyk uit die hele debat, is dat daar in Duitsland ten spyte van dekades se ekumeniese kontak, nog steeds in sekere kringe (soos die Universiteit van Tübingen) geweldige vooroordele bestaan jeens die Rooms-Katolieke Kerk en haar teologie. Verder - dat Protestantse identiteit in hierdie kringe - nog steeds verstaan word as afgrensing teenoor Rome.

Dit is vir my as 'n buitestander duidelik dat hier legitieme teologiese kritiek teen hierdie verklaring uitgespreek kan word. Of die kritiek van iemand soos Jörg Baur (dogmatikus van Gơttingen) nou cok weer geregverdig is, bly 'n vraag waarop daar seker in die toekoms duidelikheid sal kom. Baur (1989), wat al op Lehrverurteilungen Kirchentrennend? heftige kritiek gelewer het, probeer nou om mense met nog groter passie te oortuig dat konsensus met die Rooms-Katolieke Kerk oor hierdie saak net nie moontlik is nie. Baur $(1998,1999)$ meen dat hier twee teologiee teenoor mekaar staan, wat op geen wyse met mekaar versoenbaar is nie. Die twee kerke verstaan volgens hom die verhouding tussen God en mens totaal verskillend, en geen kommissie sal 'n ware konsensus bereik, indien sy lede met mekaar eerlik is nie.

Dit is egter vir my ook duidelik dat kritici nie altyd genoegsame ekumeniese sensitiwiteit openbaar vir wat hier beplan en bereik is nie. Die opstellers van hierdie verklaring word nie die krediet gegee dat hulle kerkeenheid op 'n ander manier - ja, die regte manier - as waaraan die ekumeniese bewegings ons gewoond gemaak het, probeer bevorder nie. Hierdie Kommissie werk met die oortuiging dat kerkeenheid bevorder word waar daar eenheid in leer tot stand kom. Hulle deel nie die populêre mening dat

13 Hierdie artikel konsentreer, weens 'n gebrek aan ruimte, slegs op die Protestantse resepsie van hierdie verklaring. 
cenheid tot stand kom waar etiese uitdagings gesamentlik aangepak word nie. Agter hierdie verklaring sit daar dus die wil om kerkeenheid deur teologiese gespreksvoering op 'n Bybelse grondslag te bevorder. Dít, as sodanig, is eintlik 'n wonderwerk. Om Rooms Katolieke so ver te kry om teologiese gesprekke te voer met eksegese as vertrekpunt, is 'n geweldige Reformatoriese deurbraak (Sauter 1999a:37). Hiermee word nie gesê dat hierdie Kommissie die hele Roomse teologiese metodiek verander het nie. Hierdie Kommissie het net op 'n daadwerklike wyse uitvoering gegee aan die besluite van Vaticanum II. By die Tweede Vatikaanse Konsilie (1962-1965) is daar op teologiese hervormings besluit. Daar is besluit om aan eksegete die ruimte te gee om saam met hulle Protestantse kollegas histories-kritiese wetenskap te beoefen. Spoedig het Protestante en Rooms-Katolieke eksegete dan ook gesamentlike projekte aangepak. Die mees vrugbare: die gesamentlike kommentaarreeks (Evangelisch-Katolischer Kommentar zum Neuen Testament). Hierdie gesamentlike akademiese projekte van die Bybelwetenskaplikes is in der waarheid die basis en stukrag agter hierdie verklaring. Die gesamentlike doen van eksegese het die Rooms Katolieke nader aan die Reformatoriese verstaan van die regverdigingsboodskap gebring. Hiervoor moet die nie-ekumenies-geinnteresseerde teoloe begrip en waardering ontwikkel. Daar moet besef word dat die Roomse teologie nie meer dieselfde teologie as dié van die $16 \mathrm{e}$ eeu is nie. Eksegeties het die Roomse teologie baie na aan dié van die Protestante beweeg (vgl Graßßer 1998 vir volledige inligting). Hier kan dus werklik nie sprake wees van 'n teologiese ooreenkoms onder Roomse leiding nie. Wat eerder waar is, is dat die Roomse teologie nader aan dié van die Lutherane beweeg het (Sauter 1999a:38).

Ten spyte van al hierdie positiewe dinge, bly dit onteenseglik waar dat daar talle punte van legitieme kritiek teen hierdie verklaring ingebring kan word. Daar kan byvoorbeeld oor die volgende gekla word: dat hierdie teks geen "ekumeniese" produk is nie, maar 'n tipiese Wes-Duitse produk (Wallmann 1998:231). Dat dit ietwat vergesog is om van "konsensus in grondwaarhede" te praat, terwyl daar nog soveel fundamentele verskille, en daarom geen konvergensie tussen die twee teologies bestaan nie (Jüngel 1997; Brandt 1998; Held 1998:167). Dat daar geen gemeenskaplike verklaring oor die "sola fide", wat vir Lutherane uiters belangrik is, gemaak kon word nie (Held 1998:164). Dat hier geen sprake is van 'n eenstemmige begrip van geloof nie, en dat daar om hierdie 
rede nie van 'n konsensus sprake kan wees nie (Ringleben 1998a). Dat hier nie 'n onmiskenbare samehang tussen geloof en heilsekerheid gekonstateer word nie (Ringleben 1998b).

Daar is egter één saak wat uitstaan in die debat waarna ek graag wil verwys. Dit handel oor die vraag of die regverdigingsleer "kriterium" vir kerk en teologie is? In paragraaf 18 word daar na die regverdigingsleer as 'n "onmisbare kriterium" vir kerk en teologie verwys. Hierdie terminologie het tot hewige meningsverskil aanleiding gegee veral tussen die toonaangewende dogmatici sonder, en dié met 'n ekumeniese opdrag. Eberhard Jungel (1997), het as konfessioneel gebonde Lutheraan, op 'n hoogs emosionele wyse op hierdie uitdrukking gereageer. Hy meen dat ons hier met onsinnige taalgebruik te make het. Daar kan tog nie só iets soos 'n misbare kriterium bestaan nie. Hy meen dat die voorlaaste konsep van die "Gemeenskaplike Verklaring" korrek was deur bloot van "kriterium" te praat, sonder die relativerende attribuut. Hierdie attribuut maak van die duidelike Protestantse insig, iets onduidelik en vaag. Jungel se emosionele uitbarsting het natuurlik nie slegs te make gehad met die teks as sodanig nie, maar ook met gebeure rakende die Roomse Geloofskongregasie en uitsprake van Rooms-Katolieke teoloe oor hierdie aangeleentheid. Almal (vgl Held 1998:167) is dit eens dat daar (vanuit Lutherse perspektief) groot vordering gemaak is deur die Rooms Katolieke só ver te kry om te erken dat die regverdigingsleer nie slegs 'n belangrike deel van die geloofsleer is nie, maar dié "maatstaf vir leer en praktyk van die kerk". Binne die Kommissie was daar konsensus oor hierdie saak. Joseph Ratzinger kon dit egter nie aanvaar nie. Hy het die Rooms-Katolieke afvaardiging gedwing om hulle standpunt te verander (vgl Kalinna 1998:159). Onder sy druk het Walter Kasper, mede-opsteller van die Verklaring, biskop van Rottenburg en Roomse kollega van Jüngel in Tubingen, dan byvoorbeeld later gesê dat die regverdigingsleer nie eksklusiewe betekenis het nie (soos wat daar coreengekom is), aangesien hierdie oortuiging die rykdom van die Bybelse getuienis op hierdie wyse ondergrawe. Volgens Jungel staan die boodskap van die regverdiging nie op dieselfde vlak met die boodskap van vrede, heiliging ensovoorts nie. Dit is die sentrale boodskap, die hart en kem van die evangelie, waaruit die ander aspekte van die evangelie voortvloei. Om hierdie rede mag die Lutherane volgens hom nie vrede hê met hierdie uitspraak nie. Reinhard Schwarz (1998), bekende Lutherkenner, is dit met Jüngel honderd 
persent eens oor hierdie hele aangeleentheid. Die Fin, Risto Saarinen, ekume-niese teoloog van Straßburg, is egter van oortuiging dat hier nie van teologiese verraad sprake is nie. Saarinen (1998) meen dat die Lutherane eerder op teologiese sukses aan-spraak kan maak, aangesien die gebruik van die term "kriterium" tipies Reformatories is. Hy wys daarop dat die oorsprong van hierdie taalgebruik teruggaan op die Confessio Augustana Artikel VII. Die volle versameling van die Lutherse Wêreldbond het in 1963 te Helsinki op grond van die CA geoordeel dat die regverdigingsleer die "hermeneutiese kategorie" is wat al ons denke, spreke en handeling bepaal. In 1970 is daar in Evian gesê dat die vashou aan die regverdiging deur die geloof alleen, die enigste kriterium vir kerkgemeenskap is. Die "Leuenberger Konkordie" (die ooreenkoms tussen Lutherane en Calviniste) van 1973 het ook van die regverdigingsboodskap as die "maatstaf van alle verkondiging van die kerk" gepraat. Hierdie kerklike begripsmateriaal is deur die Protestantse teologie gevoed. Dit was veral Martin Kähler (Die Wissenschaft der christlichen Lehre, $1893^{2}$ ) wat hierdie taalgebruik bevorder het. Hy het 'n saak daarvoor uitgemaak dat die regverdigingsleer die middelpunt van die dogmatiek moet wees, waar rondom alles opgebou moet word. Niemand minder nie as Rudolph Hermann en Paul Tillich het hom hierin gevolg. Verder was dit veral die teologie van die Duitse kerkstryd, wat in die sogenaamde "Dialektiese Teologie" uitgeloop het, wat deurslaggewende invloed in hierdie verband uitgeoefen het. Karl Barth, en veral Ernst Wolff (Die Rechtfertigungslehre als Mitte und Grenze reformatorischer Theologie, 1949) asook Hans Joachim Iwand (Rechtfertigungslehre und Christusglaube, 1930), het hier 'n deurslaggewende rol gespeel. Hulle het die regverdigingsleer, as die hart van die evangelie, gebnuik om die kerk te bevry van die ideologie van die Nasionaal-Sosialisme. Verder wys Saarinen (1998:91-94) ook daarop dat die gebruik van die term "kriterium" al lankal in ekumeniese dokumente oorgespoel het. Die "Malta-berig" van 1973 het al van die regvendigingsleer as "kriterium" gepraat. Die Amerikaanse Luthers/Rooms-Katolieke gespreksdokument "Regverdiging deur die geloof" (1983) het gestel dat die regverdigingsleer die kriterium is vir die outentisiteit van die verkondiging en praxis van die kerk is. Teen hierdie agtergrond meen Saarinen, dat dit al vanselfsprekend is, dat daar in die huidige ekumeniese teologie van die "metadogmaties-kriteriologiese betoog" van die regverdiging gepraat word. Ter wille van ekumenisiteit, meen hy (en mense soos Held 
1998:167), dat die relativerende "onmisbaar" maar gelaat kan word, aangesien die Lutherane tog in 'n groot mate hulle sin gekry het. Wanneer die Rooms Katolieke nou ook die regverdigingsleer "kriterium" van die teologie noem, beteken dit dat die regverdigings-leer ook tot "Kritiese instansie vir die beoordeling van die waarheid van hulle teologie" verhef word (1998:90).

Gerhard Sauter (1999a, 1999b), dogmatikus en hoof van die ekumeniese instituut in Bonn, het ook 'n bydrae gelewer tot die "kriterium-debat". Volgens hom het ons hier met 'n voorbeeld van 'n "spraakreeling" in ekumeniese debatvoering te make. 'n Spraakreeling wil die gemeenskaplike na vore bring, en die verskille versteek. Hy wys daarop dat niemand dit kan betwyfel dat daar belangrike ooreenkomste tussen Lutherane en Rooms Katolieke bereik is nie, maar dat dit ook nie betwyfel kan word dat daar nog steeds ernstige verskille bestaan nie. Volgens hom moet almal nou met hierdie "spraakreelling" saamleef: in dankbaarheid dat daar sprake is van toenemende konsensus, maar cok in onrus dat volle ooreenstemming nog ver is.

As ekumeniese dogmatikus meen Sauter dat die eenheid tussen Lutherane en Rooms Katolieke vinniger sal vorder wanneer daar nie meer van die regverdigingsleer as "kriterium" gepraat sal word nie, maar van "dié dialoogreêl van die kerk". Die regverdigingsleer rig ons oê op Jesus Christus as die gestalte van God se rigtende en reddende handeling van God. Hierdie boodskap is 'n vreemde boodskap wat van buite onsself, ongevraagd aan ons geskenk is. Dit is die boodskap dat God gehandel het om ons van ons verlorenheid te red, aangesien ons nie in staat is om onsself te red nie, en dat Hy gehandel het nog voordat ons dit nog oorweeg het om ons tot Hom te wend. Hierdie leer vorm saam met die triniteitsleer en die twee-nature-leer die basis van alle regte teologie. As 'n "topiese artikel" maak dit ons daarom bekend met die hartslag van die Christologie: die redes hoekom ons God Vader mag noem. Hierdie artikel is as hoofartikel daarom verantwoordelik vir die gestaltegewing van die totale teologie. Die regverdigingsleer hoef nie nog uitgelê en of geinnterpreteer word nie. Dit is die beginpunt, die basis van alle teologie. Om hierdie rede kan dit as dialoogreel funksioneer. Dit stel gespreksgenote in staat om by 'n punt te begin waaroor daar nie meningsverskil hoef te bestaan nie. Dit open 'n gesprek met uitsprake wat in elk geval vroekr of later gemaak sal moet word. Sauter meen dus dat dit tragies is dat daar na konsensus oor die regverdigingsleer gesoek word. Die regverdigingsleer behoort die konsensus te wees wat 
gelowiges van verskillende kerke in staat stel om met mekaar verder oor die teologie te praat.

Samevatting: die "Gemeenskaplike Verklaring" is in 'n groot mate 'n balans oor dit wat tot hiertoe bereik is met die dialoogvoering oor die laaste dekades. Hierdie balans sê wat die kerke gemeenskaplik kan bely, en in hoeverre daar nog verskille bestaan, wat egter nie van kerkskeurende gehalte is nie. Daar bestaan met ander woorde konsensus oor dít waaroor daar saamgestem word en oor dit waaroor daar verskil word. Die een veroordeel nie meer wat die ander leer nie, en leer nie meer wat die ander een veroordeel nie. Dít beteken egter nie dat daar leerkonsensus oor die regverdiging bestaan nie. Leerkonsensus word nog nagestreef. Dit is 'n doelwit wat nagejaag sal word. Dit moet ook gesê word dat 'n groep teoloẽ ook nie konsensus tussen kerke kan skep nie. In hierdie spesifieke geval (die regverdigingsleer) word konsensus enersyds bemoeilik deur die Roomse ortodoksie van die Roomse Geloofskongregasie, en andersyds deur die leermoegheid en selfs leervyandigheid van sekere mense in die Lutherse kerkleiding (Sauter 1999a:38). Óf volle konsensus ooit bereik gaan word, moet maar gesien word. Dit is in elk geval vir sekere kerkleiers soos Hermann Kalinna (1998:160) duidelik dat die Roomse genadeleer, wat die middelaarskap van Maria moontlik maak (dit het die pous op 1 Okt 1997 herbevestig), in die weg staan van volle konsensus. Mariologie en die regverdigingsleer (Christus en die geloof alleen) staan onversoenbaar teenoor mekaar. Tog is daar aan die ander kant ook nou weer mense soos Reinhard Brandt (1998:71-73) wat juis meen dat hierdie verklaring 'n bewys is dat die Rooms-Katolieke Kerk (of minstens toonaangewende teolos in hierdie kerk) ten opsigte van haar genadeleer wegbeweeg het van Trente, en baie na aan die Lutherane kom staan het. Om hierdie rede meen Theobald (1998:116) dat die twee kerke mekaar nou as ware kerke kan aanvaar, en hard moet werk om verdere eenheid tussen die kerke te skep.

\section{DIE (ON)BELANGRIKHEID VAN DIE REGVERDIGINGS- LEER}

Vir talle mense sal dit 'n raaisel wees hoekom daar só 'n ophef gemaak word van 'n ooreenkoms oor die regverdigingsleer. Niemand minder nie as Martin Luther (WA TR 2, 2408b) het gesê: "wanneer 'n mens oor die artikel van die regverdiging preek slaap die volk en hoes; maar wanneer 'n mens begin om stories te vertel en voorbeelde op te noem, 
dan spits hulle beide ore, is stil en luister aandagtig toe." Hierdie waarneming en beklaging is in verskillende eeue herhaal. Johann Gottlieb Fichte (1991:348) het in 1804 gesê: "Die kerk het dit al byna opgegee om oor daardie stelling te preek; en waar sy dit nog doen, doen sy dit sonder enige vrug, aangesien niemand dit ter harte neem nie." Eugene Bizer het die waarneming gemaak dat die belangstelling in die regverdigingsleer in ons eeu maar baie beskeie is. Bizer (1967:13) het dit raak saamgevat toe hy gesê het: 'Nóg die denke van die kerk huidig, so ver mens dit uit kerk- en ampsblaaie kan vasstel, nóg die denke van die huidige teologie sentreer rondom hierdie artikel ... Dit blyk dat die teologie vandag weer geneig is om vir hulle probleme en antwoorde deur die psigologie en sosiologie te laat voorskryf, in plaas van die Skrif." Dit blyk dus baie duidelik dat hierdie leer, wat nou wel vir die Reformatore belangrik was, sy aktualiteit in die moderne tyd verloor het. Een rede vir die verlies aan aktualiteit, is die afwatering van die belangrikheid van hierdie tema deur moderne eksegete. Kritiese Paulus-navorsers soos Wrede, Schweitzer, Sanders en Dunn (kyk Lohse 1997:113-115) het talle mense oortuig dat die regverdigingsleer nie só 'n sentrale plek in Paulus se teologie innem as wat Luther gemeen het nie. 'n Ander rede vir die verlies aan aktualiteit, is dat die regverdigingsleer nie aan jongmense verduidelik word as iets wat ten diepste met hulle bestaan te make het nie. Ingrid Schoberth (1999) wys daarop dat skoliere ten diepste deur geluksvöorstellings aangedryf word. Kerklik word hierdie behoeftes dan begroet met 'n klomp geluksbeloftes binne die konteks van die moderne konsumpsiemaatskappy, wat as onderbou 'n platvloerse stuk moralisme het. Die positiewe selfbeeldvormende waarde van die regverdigingsboodskap gaan op hierdie wyse by kinders verby.

Nog 'n rede vir die verlies aan aktualiteit, is die vervaging van die verstaanshorison van die regverdigingsleer. Die verstaanshorison word gekenmerk deur 'n bepaalde vraagstelling en antwoord. Die vraag is: hoe kan die mens as wetsoortreder in die laaste oordeel voor God bestaan? Die antwoord is: danksy die offerdood van Jesus Christus word ons van ons sonde (oortreding van die wet) vergewe. Die genade van God red ons van die onuitwykbare laaste oordeel. Wet en genade, gerig en die kruis maak dus die verstaanshorison van die regverdigingsleer uit. Sedert die sestigerjare word daar met oortuiging geargumenteer dat hierdie verstaanshorison vervaag het. Daar word daarop gewys dat mense nie meer in vrees vir die eindoordeel lewe nie, dat hulle hulle self nie meer as sondaars verstaan nie, dat die doop nie meer as uitdelging van die erfsonde 
gesien word nie, maar as die eerste tree op die pad van gehoorsaamheid en dat die Nagmaal nie as vergewing van sondes gesien word nie, maar as die vier van gemeenskap (Schăfer 1993). Met die vervaging van die verstaanshorison van die regverdigingsleer, het 'n nuwe tipe teologie, wat Jürgen Moltmann (1997) die "Ryk van God teologie" noem, ontwikkel. Hierdie teologie het die klem laat verskuif van die geloof na die handeling, van die sondevergewing na die herskepping, van die heilsdade van die verlede na die heilsverwagting van die toekoms. Die volle versameling van die Lutherse Wêreldbond (Sauter 1989:14-15) het hierdie verskuiwing in verstaanshorison in 1963 in Helsinki as volg geformuleer:

Die mens van vandag vra nie meer: hoe kry ek 'n genadige God nie? Hy vra radikaler, meer elementêr, hy vra na God as sodanig: waar is U, God? Hy ly nie meer onder die toom van God nie, maar onder die indruk van God se afwesigheid; hy ly nie meer onder sy sonde nie, maar onder die sinloosheid van sy bestaan; hy vra nie meer na die genadige God nie maar of God werklik bestaan.

Die Rooms-Katolieke teoloog Hans Küng (1974:574) het hierdie waarneming nóg 'n stappie vender gevoer en soos volg geformuleer:

Vroeetr is daar in 'n (ruimte) van groot wêreld- en siele-angs gevra: hoe kry ek 'n genadige God? Vandag egter, in 'n nie kleiner wereld- en eksistensie-angs: hoe kry my lewe sin?

Vroeerr is (hierdie) God as die Regtergod verstaan wat die mens van sy sonde vry- en geregspreek. Vandag verstaan mens Hom as Bondgenoot, wat die mens in die vryheid en in verantwoordelikheid vir die wêreld en geskiedenis roep.

Vroestr het dit om die individuele regverdiging en die private "red jou siel" gegaan. Vandag gaan dit om die sosiale dimensie van die heil en die omvattende sorg vir die medemens.

Vroetr was daar die spiritualistiese besorgdheid om die hiernamaalse heil en vrede met God. Vandag is daar 'n omvattend besorgdheid oor die maatskaplike toestande en die hervorming en selfs die revolusionering van strukture. 
Vroetr was die mens onder die dwang om sy lewe voor God te regverdig. Vandag is hy onder die dwang om sy lewe teenoor homself en sy medemens te regverdig.

Ten spyte van die feit dat die regverdigingsleer in diskrediet by die eksegete, en uit die mode in die kerklike praktyk geraak het, behoort dit vir gelowiges nog steeds van uiterste belang te wees. In 1537 het Martin Luther (WA 39/I, 205, 217) in die voorrede tot die promosiedisputasie van Palladius en Tilemaan aan die Universiteit van Wittenberg die volgende oor die regverdigingsleer gesê:

Die artikel van die regverdiging is leraar en vors, heer, leidsman en regter oor al die verskillende soorte van (Christelike) leer. Hy bewaar en bestuur alle kerklike leer. Hy rig ons gewete voor God op ... Sonder hierdie artikel is die wereld net dood en duisternis; aangesien ons menslike rede sonder kennis van en nabetragting oor hierdie artikel tevredenheid vind en mislei word deur enige dwaling, hoe klein, dwaas en dom dit ook al mag wees. Gevolglik is die onderwerp nóg gering nóg hol, maar gewigtig, in die besonder vir diegene wat in die in stryd teen duiwel, sonde en die dood wil standhou en die gemeentes will leer.

Toonaangewende kritiese eksegete soos Eduard Lohse (1997) en Ferdinand Hahn het onlangs (1999) weer begin om die oortuiging uit te spreek, dat die motief van God se geregtigheid nie net tema by Paulus is nie, maar regdeur die hele Bybel voorkom. Verder is hulle daarvan oortuig dat die regverdigingsleer die grondboodskap van die Nuwe Testament is. Dit is nie maar bloot 'n tema naas ander temas nie, maar die grondtema as sodanig. Dit is niks minder nie as die hart en die grens van die teologie (E Wolff). Selfs Ou-Testamentici soos Christoph Levin (1999) aanvaar en verdedig deesdae hierdie stelling.

Die stroom van publikasies die afgelope twee dekades oor die regverdigingsleer (kyk o a na Fuhrer 1994; Sauter se studieboek 1989 asook sy leksikonartikels 1997a en $1997 \mathrm{~b}$ en die massale aantal literatuurverwysings wat daarin voorkom) lewer bewys dat die gety gelukkig besig is om te verander. Om hierdie rede verbaas dit nie dat die 
Lutherane en Rooms Katolieke dit as die belangrikste tema vir ekumeniese gespreksvoering beskou nie.

\section{AKTUALITEIT VAN DIE REGVERDIGINGSLEER}

Nuwe belangstelling in die regverdigingsleer alleen gaan nie voldoende wees om kerk en teologie weer terug te lei na die hart van die evangelie nie. Die teologie, en veral die sistematiese teologie, sal die aktualiteit van die regverdigingsleer bo alle twyfel moet aandui.

In heelwat dogmatiese publikasies van die onlangse verlede (waarvan dié van Jungel 1998b en Beintker 1998 die belangrikste is), is daar tekens van pogings om aan hierdie uitdaging gestalte te gee. Iemand soos Jürgen Moltmann, wat - soos reeds gesê nie baie waarde aan die regverdigingsleer heg nie, het in feitlik al sy laaste boeke tog met die regverdigingsleer geworstel. Hy het binne die raamwerk van sy "politieke teologie" 'n daadwerklike poging aangewend om hierdie leer te aktualiseer (kyk Moltmann 1991:137-193 vir 'n samevatting van al sy pogings). Wolfhart Pannenberg (1993:238265) het ' $n$ hele hoofstuk in sy "Sistematiese Teologie" aan hierdie tema afgestaan. Hy het vanuit die tema van die "kindskap van God" nuwe aktualiteit aan ons tema probeer gee. Ernstige pogings word aangewend om buite die metaforiek van die oordeel van God, nuwe aktualiteit aan hierdie leer te gee. Wilfried Hărle (1998) het hom al op hierdie gebied onderskei. Terselfdertyd is daar suksesvolle pogings om juis binne die raamwerk van hierdie metaforiek nuwe begrip vir die regverdigingsleer te laat ontwikkel. In hierdie opsig kan daar na die uitstekende artikel van Bauke-Ruegg (1997) verwys word. Selfs die nuutste sosiale etiek (Kortner 1999) word vanuit die regverdigingsleer ontvou.

Die een belangrike tema waaraan ek graag kortliks aandag wil gee, is dié van die "sinvraag". Uit die aanhalings van Helsinki en Hans Küng weet ons nou alreeds dat " $\sin$ " in die laaste dekades as substituut vir regverdiging aangebied word. Ook in Suid-Afrika leef hierdie denke baie sterk. Die besprekingsdokument van die Kerkbode "Geloofsverklaring 2000" sê "dat Jesus Christus aan mense se lewe sin gee". Yolanda Dreyer (1999:33) sê dat die "postmoderne teologie" daarop neerkom dat mense primêr gesien 
word as vrye en kreatiewe skeppers van sin en betekenis in hulle lewens. Die vraag is eenvoudig: het die evangelie van Jesus Christus met "sin" of met regverdiging te make?

Agter die vraag na "sin" skuil die vrae "waarheen?", "waarvandaan?", "waarom?", en "waartoe?" (Beintker 1998:95-98). Hierdie vrae is oeroue vrae van die godsdiensgeskiedenis. In die Ou Testament is daar byvoorbeeld in talle Psalms, Prediker, Job en Klaagliedere met hierdie vrae geworstel. Die kenmerkende was dat hierdie worstelings, worstelings met God was. In die Laat-Middeleeue het die vraag na "sin" 'n antropologiese toespitsing gekry. Op die grafsteen van Martinus von Bibrach (1498) staan die volgende gedig:
Ek lewe, en weet nie hoe lank nie, ek sterwe en weet nie wanneer nie, ek vaar en weet nie waarheen nie, ek verwonder my dat ek so vrolik is.

Ná die Tweede Wêreldoorlog het die antropologiese toespitsing in eksistensięle verwarring verander. Johannes Mario Simmels (Beintker 1998:98-99) het dié woorde in sy roman " $E k$ is verwonderd dat ek so vrolik is", dienooreenkomstig verander sodat dit soos volg lees:

Ek is, ek weet nie wie nie.

Ek kom, ek weet nie waarvandaan nie.

Ek gaan, ek weet nie waarheen nie.

Ek verwonder my, dat ek so vrolik is.

Vandag word die eksistensiěle verwarring geïntensifeer deurdat die moderne en postmoderne mens sy visie op transendensie al meer en meer verloor. Die werklikheid van God, die bron van ons bestaan, word verlaag tot religieuse verlenging van 'n antropologiese grondbevindelikheid. Dit beteken: die mens word op homself teruggewerp, en vereensaam. Die ver-hier-en-nou van die lewe, plaas die druk op die mens om sy lewe nou ten alle koste sin te gee. Die "sinvolle" wat nagestreef word is dit wat doelmatig, nuttig en suksesvol is. 'n Lewe (deur die mens self geskep) is "sinvol" wanneer dit 
gemaklik en genotvol is. Die konsekwensie: die mens vervreem homself van die vrae "waarvandaan" en "waarheen". Wat lê dus nou ten diepste agter hierdie "sin-skeppery"? Beintker (1998:102-103) meen, die verandering van die fundamentele vraag van die metafisika. Leibniz het gevra: "waarom is daar hoegenaamd iets en nie eerder niks nie?" Teologies omgesit: "waarom het God hoegenaamd die wêreld geskape en nie Hom en ons eerder hiervan gespaar nie?" Hierdie teodiscevraag (waarin die mens sy behoefte aan regverdiging prysgegee het, sodat hy as regverdiger van God kon optree), is in die moderne tyd in 'n antropodisee verander. Met die prysgawe van God, het die mens self die rol van skepper oorgeneem. Nou moet hy op die vraag antwoord: "met watse reg bestaan jy, en hoekom bestaan jy eerder nie, en met watse reg is jy wat jy is en soos wat jy is, en nie eerder anders nie?" Die mens het dus 'n geweldige bewyslas oor homself gebring. Om homself te bewys, skep hy "sin". Die probleem is egter dat die mens, in teenstelling tot God, nie genadig is nie. Die "sin-resultate", van wie ook al, word aanhoudend genadeloos gekritiseer. Die mens as skepper van "sin" word gecturig voor die gerig gebring, geoordeel en veroordeel. As gevolg van die "vertribunalisering" van ons menslike leefwêreld, moet daar radikale oplossings kom. Hierdie oplossings word dan gesien as die meewerking aan een of ander maatskaplike toestand wat met die "ryk van God" verbind kan word. "Sin" mond dus op een of ander wyse uit in die najaag van een of ander "utopie". En ons weet - Nietzsche het al besef - dat die voedingsbodem van die nihilisme hier te vinde is. Die oplossing vir hiendie krisis: die herontdekking van die regverdigingsleer, dan sal ons saam met Luther (WA 34/2, 275,16-19) kan sê:

\footnotetext{
Ek lewe, en weet hoe lank, ek sterwe en weet wanneer, ek gaan, en weet God sy dank, warheen, ek verwonder my dat ek so treurig is.
}

Die vraag na "sin" is duidelik 'n afgodsvraag (Sauter 1982:159-170). Dit loop uiteindelik uit op totale antwoorde. Die "laaste sin" die uiteindelike "(ge)heelheid" van alles vervang God, en is daarom niks anders as 'n afgod nie. Die regverdiging deur die geloof 
alleen begin en eindig met dít wat ons self nie kan skep nie; met dít wat ons uit genade slegs moet ontvang. Dit red ons daarvan om "sin" te probeer skep, wat ons meen die grond van ons bestaan kan word. Die regverdigingsleer kan ons in ons lewe van iets belangrik bevry: die groot lewensleuen dat "sin" van menslike dade afhanklik is (Jüngel 1998b:220-224). Die regverdiging sonder die werke van die wet, leer ons dat die mens nie sy daad is nie. Dit leer dat die mens niks vir sy heil kan doen nie. Hy doen eers dan iets "sinvol", wanneer dit niks met sy heil te make het nie. "Sinvol" is werke, wat nie 'n nuwe mens of samelewing wil of moet skep nie. Dit is "sinvol" omdat dit nie te make het met selfregverdiging nie, maar met vrye diens aan die naaste.

\section{Literatuurverwysings}

Bauke-Ruegg, J 1997. Die Frage nach dem gnädigen Gott. Erinnerungen an einige Implikationen der reformatorischen Rechtfertigungslehre. EvTh 57, 474-495.

Baur, J 1989. Einig in Sachen Rechtfertigung? Tubingen: Mohr.

Baur, J 1998. Die Rechtfertigungslehre in der Spannung zwischen dem evangelischen "Allein" und dem rơmisch-katolischen Amts- und Sakramentsverstăndnis. EvTh $58,140-155$.

Baur,' J 1999. Frei durch Rechtfertigung. Tubingen: Mohr.

Beintker, M 1998. Rechtfertigung in der neuzeitlichen Lebenswelt: Theologische Erkundungen. Tubingen: Mohr.

Bizer, E 1967. Über die Rechtfertigung, in Viering, F (Hrsg), Das Kreuz Jesu Christi als Grund des Heils, 1-20. Gütersloh: Guttersloher Verlagshaus.

Brandt, R 1998. Gemeinsame Erklärung - kritische Fragen. ZThK 95, 63-102.

Dalferth, I U 1997. Ökumene am Scheideweg. Frankfurter Allgemeine Zeitung 26 September 1997, bl 13.

Dreyer, Y 1999. Postmoderne teologie. Konteks.11(3), 33.

Evangelische Kirche in Deutschland (EKD) 1999. Pressemitteilungen. Aktuell. Rechtferigung. http://ekd.de/aktuell/presse/rechtfertigung (31 Okt 1999).

Evangelische Presse Dienst (epd). http://ekd.de/epd 
Fichte, J G 1991. Die Grundzilge des gegenwartigen Zeitalters. Vorlesungen 1804/1805. 7. Vorlesung in, Gesamtausgabe. Band 1,8. 269-272. Hrsg v Lauth, $R$ \& Gliwitzky, H. München: Bayerische Akademie der Wissenschaften.

Fuhrer, W 1994. Rechtfertigung und Heiligung bei Hans Joachim Iwand. KuD 40, 272 281.

Grane, L 1998. Die ekklesiologische Bedeutung der Rechtfertigungslehre - aus Luthers Sicht, in Zur Rechtfertigungslehre. ZThK Beiheft 10, Dez 1998, 1-13.

Graßer, E 1998. Evangelisch - katolische Exegese? ZThK 95, 185-196.

Hahn, F 1999. Gerechtigkeit Gottes und Rechtfertigung des Menschen nach dem Zeugnis des Neuen Testaments. EvTh 59, 335-346.

Härle, W 1998. Zur Gegenwartsbedeutung der "Rechtfertigungs"-Lehre, in Zur Rechtfertigungslehre. ZThK Beiheft 10, Dez 1998, 101-139.

Held, H J 1998. Ein neues Miteinander: Zur Einordnung der Gemeinsamen Erklărung zur Rechtfertigungslehre. EvTh 58, 161-168.

Hendrix, S 1997. Offene Gemeinschaft: Die kirchliche Wirklichkeit der Rechtfertigung. $K u D$ 43, 98-110.

Jenson, R 1996. Rechtfertigung und Ekklesiologie. $K u D$ 42, 202-217.

Jüngel, E 1997. Um Gottes willen - Klarheit! Kritische Bemerkungen zur Verharmlosung der kriteriologischen Funktion des Rechtfertigungsartikels - aus Anlab einer 8kumenischen "Gemeinsamen Erklärung zur Rechtfertigungslehre". ZThK 94, 394-406.

Jüngel, E 1998a. Amica Exegesis einer römischen Note, in Zur Rechtfertigungslehre. ZThK Beiheft 10, Dez 1998, 252-279.

Jüngel, E 1998b. Das Evangelium von der Rechtfertigung des Gottlosen als Zentrum des christlichen Glaubens: Eine theologische Studie in olumenischer Absicht. Tubingen: Mohr.

Kalinna, H E J 1998. Einig in der Rechtfertigungslehre? Zur Gemeinsamen Erklärung des Lutherischen Weltbundes und des Päpstlichen Rates zur Förderung der Einheit der Christen. EvTh 58, 156-161.

Kandler, K-H 1990. Rechtfertigung - kirchentrennend? KuD 36, 209-217.

Klaiber, W 1996. Rechtfertigung und Kirche. KuD 42, 285-317. 
Kơrtner, U 1999. Evangelische Sozialethik: Grundlagen und Themenfelder. Gơttingen: Vandenhoeck. (UTB 2107.)

Kung, $H$ 1974. Christ sein. Manchen: Piper.

Levin, Chr 1999. Altes Testament und Rechtfertigung. ZThK 96, 161-176.

Lohse, E 1997. Rechtfertigung und Kirche. KuD 43, 111-123.

Luther, M 1883 vv. Kritische Gesamtausgabe $(W A=$ Weimarer Ausgabe. WATR $=$ Tischreden Weimarer Ausgabe). Weimar: Herman Bohlau.

Meyer, H 1985. Konsens und Kirchengemeinschaft: Am Ende der zweiten Phase des Dialogs zwischen römisch-katolischer Kirche und Lutherischem Weltbund. KuD 31, 174-200.

Moltmann, J 1991. Der Geist des Lebens: Eine ganzheitliche Pneumatologie. München: Kaiser.

Moltmann, J 1997. Was heißt heute "evangelisch"? Von der Rechtfertigungslehre zur Reich-Gottes-Theologie. EvTh 57, 41-46.

Pannenberg, W \& Lehmann K 1986. Lehrverurteilungen - kirchentrennend? Band 1. Rechtfertigung, Sakramente und Amt. Göttingen: Vandenhoeck. (Dialog d Kirchen. Bd 4.)

Pannenberg, W 1991. Die Rechtfertigungslehre im 8kumenischen Gespräch.: ZThK 88, 232-246.

Pannenberg, W 1992. Müssen sich die Kirchen immer noch gegenseitig verurteilen? $K u D$ 38, 311-330.

Pannenberg, W 1993. Systematische Theologie, Band 3. Göttingen: Vandenhoeck.

Ringleben, J 1998a. Der Begriff des Glaubens in der "Gemeinsamen Erklărung zur Rechtfertigungslehre". ZThK 95, 232-249.

Ringleben, J 1998b. Heilsgewißheit: Eine systematische Betrachtung, in Zur Rechtfertigungslehre. ZThK Beiheft 10, Dez 1998, 65-100.

Saarinen, R 1998. Die Rechtfertigungslehre als Kriterium. KuD 44, 88-103.

Sauter, G 1982. Was heißt: nach Sinn fragen?: Eine theologisch-philosophische Orientierung. München: Kaiser. (Kaiser Traktate 53.)

Sauter, G 1989. Rechtfertigung als Grundbegriff evangelischer Theologie: Eine Textsammlung eingeleitet und herausgegeben von Gerhard Sauter. Munchen: Kaiser. (Theol Bücherei 78.) 
Sauter, G 1997a. s v Rechtfertigung. Dogmatisch. TRE Band 28, 352-364.

Sauter, G 1997b. God creating faith: The doctrine of justification from the Reformation to the present. Lutheran Quarterly XI(1), 17-102.

Sauter, G 1999a. Rechtfertigung - eine anvertraute Botschaft: Zum unentschiedenen Streit um die "Gemeinsame Eklărung zur Rechtfertigungslehre". EvTh 59, 32-48.

Sauter, G 1999b. Die Rechtfertigungslehre als theologische Dialogregel: Lehrentwicklung als Problemgeschichte? OR 48, 275-295.

Schäfer, R 1993. Erfahrungsbericht: Theologie des Kreuzes in Gottesdienst und Predigt. $K u D$ 39, 90-99.

Schoberth, I 1999. Rechtfertigung und Schulersehnsucht: Zentralartikel ohne Resonanz? EvTh 59, 49-61.

Schwarz, R 1998. Luthers Rechtfertigungslehre als Eckstein der christlichen Theologiẻ und Kirche, in Zur Rechtfertigungslehre. ZThK Beiheft 10, Dez 1998, 14-46.

Schwarzwaller, K 1989. Rechtfertigung und Ekklesiologie in den Schmalkaldischen Artikeln. KuD 35, 84-105.

Slenczka, R 1987. Gerecht vor Gott durch den Glauben an Jesus Christus: Das Verstandnis der Rechtfertigung in der evangelischen Kirche und die Verstandigung ubber Rechtfertigung mit der römisch-katolischen Kirche. NZSTh 29, 294-316.

Thaidigsmann, E 1997. Das Urteil Gottes und der urteilende Mensch: Gerechtigkeit Gottes in Jesus Christus bei Hans Joachim Iwand. NZSTh 39, 285-303.

Theobald, M 1998. Rechtfertigung und Ekklesiologie nach Paulus: Anmerkungen zur “Gemeinsamen Erklårung zur Rechtfertigungslehre". ZThK 95, 103-117.

Volk, E 1988. Verlorenes Evangelium. $K u D$ 34, 122-165.

Wainwright, G 1999. Rechtfertigung: Lutherisch oder Katholisch? KuD 45, 182-206.

Wallmann, J 1998. Der Streit um die "Gemeinsame Erklărung zur Rechtfertigungslehre", in Zur Rechtfertigungslehre. ZThK Beiheft 10, Dez 1998, 207-251.

Wendebourg, D 1996 "Kirche und Rechtfertigung": Ein Erlebnisbericht zu einem neueren 8kumenischen Dokument. ZThK 93, 84-100.

Wendebourg, D 1998. Zur Entstehungsgeschichte der "Gemeinsamen Erklărung", in Zur Rechtfertigungslehre. ZThK Beiheft 10, Dez 1998, 140-206. 